\title{
Penguatan Sektor Pertanian Melalui Bank Wakaf Tani Berbasis Mudharabah
}

\author{
Istiqomah $^{1}$ Miftahul Hasanah $^{2}$ \\ Universitas Muhammadiyah Jember \\ Istikomah@unmuhjember.ac.id
}

\begin{abstract}
One of Islamic philanthropy that is developing at this time is cash waqf. Cash waqf is considered to have a higher level of flexibility compared to traditional waqf. In Indonesia, the practice of empowering waqf is still not optimal. The community paradigm regarding waqf is still limited to the issue of worship. To encourage cash representation in the community, it is not enough to do it by means of socialization and education. The government must provide exemplary cash representation to the public. By using exploratory methods, the authors present the concept of government modeling through the Wakaf Tani Bank to strengthen the agricultural sector in Indonesia. The concept of Bank Wakaf Tani is a cash waqf from the Ministry of Agriculture that is intended for underprivileged farmers. With the mudharabah scheme, Bank Wakaf Tani is expected to be a partner for farmers towards prosperity. Overall this paper has a mission to encourage cash waqf empowerment models to become a reference for cash waqf empowerment in order to improve the welfare of the nation.
\end{abstract}

Keywords: Farmer Waqf, Mudharabah

\begin{abstract}
Abstrak
Salah satu filantropi Islam yang berkembang pada saat ini adalah wakaf tunai. Wakaf tunai dinilai memiliki tingkat fleksibilitas yang lebih tinggi dibandingkan dengan wakaf tradisional. Di Indonesia, praktek pemberdayaan wakaf masih belum optimal. Paradigma masyarakat tentang wakaf masih terbatas pada persoalan ibadah. Untuk mendorong giat berwakaf tunai di masyarakat, tidak cukup dilakukan dengan cara sosialisasi dan edukasi. Pemerintah harus memberikan keteladanan berwakaf tunai kepada masyarakat. Dengan menggunakan metode eksploratif, penulis menyajikan konsep keteladanan pemerintah melalui Bank Wakaf Tani untuk menguatkan sektor pertanian di Indonesia. Konsep Bank Wakaf Tani merupakan wakaf tunai dari Kementerian Pertanian yang diperuntukkan bagi petani kurang mampu. Dengan skema mudharabah, Bank Wakaf Tani diharapkan mampu menjadi mitra bagi petani untuk menuju kesejahteraan. Secara keseluruhan makalah ini memiliki misi untuk mendorong model-model pemberdayaan wakaf tunai untuk dapat menjadi acuan pemberdayaan wakaf tunai dalam rangka meningkatkan kesejahteraan bangsa.
\end{abstract}

Kata Kunci: Wakaf tani, Mudhorobah

\section{PENDAHULUAN}

Salah satu filantropi Islam yang mengalami perkembangan sangat pesat adalah wakaf. Wakaf dinilai lebih fleksibel dibandingkan dengan filantropi keuangan Islam yang lain seperti zakat, infaq dan shadaqah. Wakaf memiliki keberpihakan yang sangat tinggi terhadap orang miskin. 
Keberpihakan tersebut terlihat pada dua poin inti esesnsi wakaf, yaitu kekekalan harta wakaf dan kemanfaatan yang berkelanjutan (Stibbard, Russell, \& Bromley, 2012).

Di Indonesia, diskursus mengenai wakaf sebagai salah satu instrument keuangan yang sangat potensial terbilang masih sangat baru. Pembahasan mengenai wakaf terdahulu lebih banyak dilakukan secara konservatif dan tradisonal, yang menempatkan wakaf pada posisi ajaran murni (ibadah mahdhah). Asset wakaf masih berupa harta tidak bergerak seperti tanah yang pemanfaatannya terbatas pada tempat-tempat ibadah (masjid, musholla), dan sarana pendidikan (sekolah, pendirian pondok pesantrean). Geliat kebangkitan wakaf dimulai dengan diskursus mengenai wakaf produktif yang diiringi dengan inovasi wakaf berupa sukuk linked wakaf dan wakaf tunai (Ahmad Atabik, 2014).

Sukuk Linked Wakaf (Sulaf) pada dasarnya merupakan kolaborasi antara instrument pembiayaan sukuk dengan wakaf yang diharapkan mampu mengoptimalkan manfaat asset wakaf yang tidak produktif (iddle asset). Sulaf diharapkan menjadi salah satu sumber pendanaan untuk mengelola wakaf secara produktif dan professional. Melalui sulaf ini, asset wakaf tidak lagi diberdayakan dalam bentuk kuburan, masjid dan sarana pendidikan. Pemberdayaan asset wakaf melalui sulaf ini dikelola secara professional dan modern dalam bentuk pembangunan apartemen, ruko, mall dan lain sebagainya yang bisa disewakan berkali-kali lipat (Khoiruddin,tt). Bahkan, hasil pemberdayaan wakaf melalui sulaf ini, dapat memberikan kontribusi positif terhadap pembangungan infrastrukstur negara.

Selain sulaf, diskursus mengenai wakaf yang terbilang masih sangat baru adalah wakaf tunai (cash waqf). Kemunculan wakaf tunai di Indonesia semakin kuat dengan respon positif dari Majelis Ulama Indonesia (MUI) yang memperbolehkan praktek wakaf uang dengan syarat nilai pokok wakaf dapat dijamin kelestariannya dan dapat dimanfaatkan untuk masa yang tidak terbatas baik untuk kemaslahatan individu maupun kelompok masyarakat. (Lubis, 2010). Kehadiran wakaf tunai semakin dirasakan oleh masyarakat dengan dibentuknya Bank Wakaf Mikro pada tahun 2017. Hingga pada Maret 2018 terdapat 20 Bank Wakaf Mikro di lingkungan pondok pesantren yang tersebar di wilayah Cirebon, Bandung, Ciamis, Serang, Lebak, Purwokerto, Cilacap, Kudus, Klaten, Yogyakarta, Surabaya, Jombang, dan Kediri (sikapiuangmu.ojk.go.id)

Bank Wakaf Mikro ini berbentuk Lembaga Keuangan Mikro Syariah (LKMS) yang memiliki asset wakaf paling tidak 3 milliar hingga 4 milliar yang berasal dari para donatur dengan biaya awal satu juta perorang. Menurut hemat penulis, kondisi ini akan menyulitkan Bank Wakaf Mikro untuk berkembang, hal ini dikarenakan sulitnya Bank 
Penguatan Sektor Pertanian Melalui Bank Wakaf Tani Berbasis Mudharabah

Wakaf Mikro ini berdiri karena untuk mengumpulkan nominal 3 sampai 4 milliar bukanlah suatu hal yang mudah. Paradigma masyarakat tentang wakaf masih terbatas pada keperluan religious. Tingkat kesadaran masyarakat untuk berwakaf secara tunai masih sangat minim. Potensi wakaf tunai sangatlah besar di Indonesia, sebagaimana diajukan oleh Mustafa Edwin Nasution dari Universitas Indonesia, dengan asumsi bahwa terdapat 10 juta kaum muslimin berpendapatan menengah yang rutin berwakaf uang setiap bulan sebesar Rp 100 ribu, maka setiap bulan dapat terhimpun dana sebesar setidaknya satu trilliun perbulan atau sekitar dua belas trilliun per tahun. Namun, pada faktanya potensi tersebut belum tergali. Selain itu, asset wakaf tunai pada Bank Wakaf Mikro lebih banyak dirasakan oleh pedagang kecil dan sangat jarang sekali diakses oleh petani. Padahal sektor pertanian merupakan salah satu sektor yang paling potensial untuk dimaksimalkan guna mengangkat perekonomian bangsa (Bank Indonesia . 2016).

Kondisi ini perlu mendapatkan perhatian. Raditya Sukmana,dengan gagasannya yang dikenal dengan wakaf APBN memaparkan bahwa untuk meningkatkan pemahaman serta kesadaran wakaf tunai kepada masyarakat diperlukan langkah nyata berupa keteladanan dari pemerintah. Keteladanan berwakaf dari pemerintah dapat berasal dari individu-individu yang mengisi struktur pemerintahan melalui tindakan wakaf pribadi, maupun melalui institusi pemerintahan yang mereka pimpin. (www. republika.co.id, 2016).

Oleh karenanya, berangkat dari konsep wakaf APBN tersebut,penulis menyajikan suatu konsep solusi terhadap optimalisasi sektor pertanian melalui Bank Wakaf Tani (BWT) yang sumber pendanaannya berasal dari asset wakaf tunai yang dikeluarkan oleh Kementerian Pertanian. Berbeda dengan konsep Sulaf, praktek BWT berbasis pertanian (muzara'ah), jauh lebih sederhana. BWT berbasis muzara'ah digelontorkan untuk membiayai petani yang tidak mempunyai lahan pertanian, pembiayaan ini dapat berupa pembiayaan sewa lahan maupun pengadaan bibit pertanian beserta dengan pendampingan pengolahan lahan pertanian. Hingga pada akhirnya petani tersebut mandiri dan asset wakaf tunai dapat digelontorkan pada petani yang lainnya. Dalam penelitian ini penulis menghadirkan skema pendanaan wakaf tunai berbasis muzara'ah beserta dengan konstruksi akad yang digunakan dalam konsep BWT berbasis muzara'ah.

\section{METODOLOGI PENELITIAN}

Proses penyusunan penelitian ini menggunakan metode eksploratif yang dilaksanakan melalui pendekatan studi literatur tentang wakaf produktif, wakaf tunai serta menggali kajian-kajian dari penelitian sebelumnya tentang bagaimana mengoptimalisasikan wakaf melalui 
paradigm wakaf produktif dan wakaf tunai. Sehingga diharapkan penelitian ini dapat lebih memberikan acuan implementasi pengoptimalisasian sektor pertanian melalui wakaf berbasis mudharabah.

\section{PEMBAHASAN}

\section{Pemberdayaan Aset Wakaf Tunai (Cash Waqf) Melalui Bank Wakaf Tani Berbasis Muzara'ah}

Direktorat Pemberdayaan Wakaf mendefinisikan wakaf tunai sebagai wakaf yang dilakukan oleh seseorang, kelompok orang, dan lembaga atau badan hukum dalam bentuk uang tunai (Tim Direktorat Pemberdayaan Wakaf, 2007: 3). Definisi wakaf ini sejalan dengan paradigma wakaf ditinjau dari perspektif ekonomi. Selain menahan harta, mengambil manfaat dengan tanpa menghabiskan atau merusakkan keadaan bendanya, perspektif ekonomi memandang wakaf sebagai pengalihan dana (atau asset lainnya, baik asset mati maupun asset bergerak) dari keperluan konsumsi dan kemudian menginvestasikannya ke dalam asset produktif yang menghasilkan pendapatan untuk konsumsi di masa yang akan dating baik oleh individual ataupun kelompok (Wadjdy dan Mursyid, 2007: 30).

Hukum keabsahan wakaf tunai memang menjadi perdebatan dikalangan Ulama'. Bahkan, sebagian besar Ulama' mengharamkan praktek wakaf tunai. Meski demikian, terdapat sebagian Ulama' yang memperbolehkan, salah satunya Ulama mazhab Hanafi. Menurut mazhab Hanafi, praktek wakaf tunai dibolehkan dengan syarat harus menjadikannya sebagai modal usaha dengan cara mudharabah atau mubadha'ah, dan keuntungannya disedekahkan kepada pihak wakaf (Ahmad Atabik, tt: 85)

Sejarah telah mencatat bahwa praktek wakaf tunai telah diparaktekkan oleh mazhab Hanafi. Praktek wakaf tunai yang terjadi pada mulanya tetap menyebutkan wakaf tanah. Dalam artian uang yang diwakafkan dikonversikan dalam bentuk tanah. Suatu contoh pembangunan masjid memerlukan tanah seluas 500 meter persegi, dengan harga 100.000.000,- ; kemudian tanah tersebut dikapling menjadi 500 kapling. Dari pembagian kapling ini maka diperoleh harga 200 ribu per kaplingnya. Tanah kapling inilah yang kemudian dilelang untuk menghimpun dana dari masyarakat.

Dalam konteks hirarki perundang-undangan di Indonesia, kehadiran wakaf tunai memang belum memiliki tempat. Undang-Undang No. 21 Tahun 2014 tentang Wakaf tidak menyebutkann secara eksplisit definisi tentang wakaf tunai. Meskipun demikian, Pasal 28 UndangUndang tersebut menyebutkan tentang tatacara pengelolaan wakaf tunai. Kehadiran wakaf tunai semakin kuat kedudukannya setelah mendapatkan respon positif dari MUI yang pada 11 Mei 2002 telah 
Penguatan Sektor Pertanian Melalui Bank Wakaf Tani Berbasis Mudharabah

mengeluarkan tentang kebolehan wakaf uang tunai. Pembolehan praktek wakaf tunai ini dengan syarat nilai pokok wakaf dijamin kelestariannya dan dapat dimanfaatkan sampai waktu yang tidak terbatas (Lubis. 2010: 103). Mengutip pendapat Mundzhir Qahaf yang menyatakan bahwa salah satu hal yang menjadi penyebab keabsahan wakaf produktif dalam Islam adalah karena bentuknya yang sangat potensal untuk dikembangkan. Bahkan lebih jauh Qahaf memberikan analisis bahwa untuk menjaga keberlangsungan wakaf diperlukan langkah nyata. Langkah tersebut dapat berupa menyisihkan harta benda wakaf yang produktif dari umat Islam untuk kesejahteraan umat (Qahaf, 2004 : 61)

Potensi wakaf tunai di Indonesia sangat besar. Namun, hingga saat ini belum ada data statistik yang memaparkan secara riil besaran asset wakaf tunai tersebut. Kondisi ini sangat berbeda dengan banyaknya datadata statistik yang memaparkan besaran asset tanah wakaf yang dapat dikembangkan. Sejauh ini, besaran asset wakaf tunai masih sebatas potensi dan wacana. Seperti halnya dipaparkan oleh Mustafa Edwin Nasution, yang berasusmsi terdapat sebesar 10 juta jiwa umat Muslim yang dermawan dengan rata-rata penghasilan Rp. 500.000,- hingga Rp. 10.000.000,- , maka paling tidak akan terkumpul dana sekitar 3 trilliun per tahun dana wakaf tunai (Mustafa Edwin Nasution, 2006 : 44).

\begin{tabular}{l|l|l|l|l}
\hline $\begin{array}{c}\text { Tingkat } \\
\text { Penghasilan/ } \\
\text { bulan }\end{array}$ & $\begin{array}{l}\text { Jumlah } \\
\text { Muslim }\end{array}$ & \multicolumn{1}{|c|}{$\begin{array}{c}\text { Besar } \\
\text { Wakaf/bulan }\end{array}$} & $\begin{array}{l}\text { Potensi } \\
\text { wakaf } \\
\text { tunai/bula } \\
\text { n }\end{array}$ & $\begin{array}{l}\text { Potensi wakaf } \\
\text { uang/tahun }\end{array}$ \\
\hline Rp. 500.000,- & 4 juta & Rp. 5.000,- & $\begin{array}{l}\text { Rp. 20 } \\
\text { milyar }\end{array}$ & Rp. 240 milyar \\
\hline $\begin{array}{l}\text { Rp. 1 juta s/d } \\
2 \text { juta }\end{array}$ & 3 juta & Rp. 10.000,- & $\begin{array}{l}\text { Rp. } \\
\text { milyar }\end{array}$ & Rp. 360 milyar \\
\hline $\begin{array}{l}\text { Rp. 2 juta s/d } \\
5 \text { juta }\end{array}$ & 2 juta & Rp. 50.000,- & $\begin{array}{l}\text { Rp. } \\
\text { milyar }\end{array}$ & Rp. 1,2 trilliun \\
\hline $\begin{array}{l}\text { Lebih dari Rp } \\
5 \text { juta }\end{array}$ & 1 juta & Rp. 100.000,- & $\begin{array}{l}\text { Rp. } 100 \\
\text { milyar }\end{array}$ & Rp. 1,2 trilliun \\
\hline
\end{tabular}

Sumber: Mustafa Edwin Nasution (2006)

Dapat terlihat betapa besar potensi asset wakaf tunai yang dapat dihimpun di Indonesia. Namun, faktanya justru berbanding terbalik dengan gambaran potensi yang telah dipaparkan. Kondisi ini sekaligus menggambarkan bahwa upaya pengoptimalan asset wakaf tunai belum maksimal. Edukasi serta sosialisasi terkait wakaf tunai perlu digencarkan 
lebih intens. Paradigma masyarakat tentang wakaf sebagian besar masih sebatas pada persoalan ibadah yang bersifat vertikal. Sehingga wakaf lebih banyak teraplikasi dalam wujud benda tidak bergerak. Disamping sosialisai dan edukasi, dalam upaya optimalisasi asset wakaf tunai di Indonesia, maka diperlukan keterlibatan langsung dari pemerintah. Bentuk keterlibatan pemerintah dapat berupa memunculkan trend berwakaf tunai. Trend berwakaf ini dapat dimulai dengan individuindividu yang mengisi struktur pemerintahan maupun melalui institusi pemerintahan secara langsung.

Untuk memaksimalkan potensi wakaf, maka harta wakaf harus dikelola dan diberdayakan dengan menegemen yang baik dan modern. Pemberdayaan wakaf ini mutlak dperlukan dalam rangka menjalin kekuatan ekonomi umat demi meningkatkan kesejahteraan masyarakat banyak. Tentu saja pemberdayaan ini membutuhkan kerja sama sari semua pihak, terutama dunia perbankan yang mempunyai kekuatan pendanaan untuk memberikan pinjaman atau lembaga-lembaga pihak ketiga lainnya yang tertarik dengan pengembangan wakaf. Kerjasama kemitraan ini sejatinya memerlukan dukungan dan komitmen yang kuat oleh semua pihak seperti umara' (pemerintah), tokoh masyarakat (ulama'), kaum professional, cendekiawan, pengusaha, perbankan dan sebagainya. Sehingga potensi wakaf dapat dimaksimalkan agar mempunyai peranan yang signifikan dalam tatanan ekonomi nasional (Tim Direktorat Pemberdayaan Wakaf Kemenag RI, 2007: 93).

Sebagai negara dengan jumlah muslim terbesar di dunia, Indonesia memiliki potensi pemberdayaan wakaf tunai. Namun, hingga saat ini potensi wakaf sebagai instrument kebajikan bagi kepentingan masyarakat belum dikelola dan diberdayakan secara maksimal. Praktek pemberdayaan wakaf secara professional justru dikembangkan di negaranegara dengan muslim sebagai minoritas penduduknya. Beberapa program pemberdayaan wakaf dari beberapa negara yang telah sukses dan mengambil peran vital diantara Bangladesh dengan program SIBLnya, Saudi Arabia dengan Zam-Zam Towernya. Bahkan Indonesia masih tertinggal oleh Singapura yang notabenenya berpenduduk mayoritas non muslim. Singapura melalui MUIS telah berhasil mengelola wakaf secara professional dan modern (Karim, 2011: 9-10). Hal ini tentu menjadi tamparan keras bagi Indonesia untuk lebih khusus mendalami persoalan pemberdayaan wakaf.

Menurut Raditya Sukmana, trend berwakaf yang dimulai dari institusi pemerintahan merupakan suatu bentuk keteladanan yang dapat mendorong budaya berwakaf di kalangan masyarakat. Hal ini sejalan dengan teori The Leadership Challenge dari Kouzes dan Posner. Salah satu konsep kepemimpinan Kouzes dan Posner adalah bahwasanya pemimpin yang terbaik adalah pemimpin yang menginspirasikan visi bersama 
Penguatan Sektor Pertanian Melalui Bank Wakaf Tani Berbasis Mudharabah

dengan cara mencontohkan caranya. Bahkan Islam terlebih dahulu telah mengenal konsep Uswatun Hasanah. Uswatun Hasanah adalah gelar yang disematkan pada Rasulullah yang bermakna teladan yang baik. Artinya, hendaknya pemimpin, yang dalam konteks ini adalah pemerintah menjadi teladan untuk mendorong praktif wakaf tunai.

Praktek keteladanan pemerintah dalam mendorong wakaf telah dimulai oleh Kementerian Agama yang pada tahun 2006 memberikan wakaf tunai sebesar 2 milliar kepada Rumah Sakit Islam Universitas Islam Malang (RSI Unisma). Melalui program wakaf ini, dihasilkan ruang rawat inap VIP dan minimarket Al Khaibar. Baik ruang rawat inap VIP maupun minimarket Al Khaibar, keduanya dikelola secara professional dan komersil. Laba yang diperoleh dari pengelolaan secara produktif inilah yang kemudian ditashaarufkan untuk kepentingan umum, seperti membiayai para dai dan guru TPA yang ada di sekitar RSI Unisma.

Keberhasilan Kementerian Agama ini perlu diteruskan dan diikuti jejaknya oleh institusi pemerintahan yang lain. Salah satunya adalah Kementerian Pertanian. Hal ini mengingat potensi pertanian yang ada di Indonesia sangat besar untuk dikembangkan.. Indonesia memiliki 220 komoditas yang 50 diantaranya memiliki keunggulan komparatif dalam pangsa global dari segi kualitas, seperti kelapa sawit, karet kering, kopra, minyak kelapa dan lain-lain. (Bank Indonesia : 18).

Kementerian Pertanian dapat menggolontorkan dananya melalui kelompok-kelompok tani. Dengan dana ini dibuat Bank Wakaf Tani dengan pengurus kelompok tani sebagai pengelolanya. Bank Wakaf Tani inilah yang kemudian berfungsi untuk menyalurkan dana pembiayaan untuk para petani. Adapun akad yang digunakan adalah akad mudharabah. Akad mudharabah, menurut hemat penulis merupakan akad yang paling fleksibel dan elastis untuk diterapkan. Hal ini dikarenakan dana wakaf yang ditempatkan dalam konsep Bank Wakaf Tani digunakan untuk pengelolaan pertanian. Konsep Bank Wakaf Tani tidak menggunakan sukuk, karena dalam konsep Bank Wakaf Tani yang menjadi wakif (orang yang berwakaf) adalah Kementerian Pertanian. Konsep sukuk mengharuskan adanya penerbitan sertifikat sukuk oleh pihak yang membutuhkan dana. Sasaran dari Bank Wakaf Tani adalah para petani yang kekurangan modal. Jikalau petani yang membutuhkan modal harus terlebih dahulu menerbitkan sertifikat sukuk untuk mendapatkan modal dari Bank Wakaf Tani, maka prosedur ini akan memberatkan petani serta menghambat tujuan dari konsep Bank Wakaf Tani yang bertujuan untuk memudahkan petani dalam mengakses modal.

Konsep Bank Wakaf Tani diperuntukkan untuk mendanai kegiatan pertanian. Namun pada prakteknya, konsep Bank Wakaf Tani tidak menggunakan akad-akad pertanian seperti muzara'ah, maupun mukhabarah. Baik muzara'ah maupun mukhabarah, keduanya merupakan 
akad kerja sama dalam bidang pertanian yang mengharuskan salah satu pihak memiliki (baik hak milik sempurna maupun hak atas manfaat) lahan (Wahbah Zuhaili, 2008 : 482). Konsep Bank Wakaf Tani lebih luas dari akad muzara'ah dan mukhabarah. Penggelontoran dana wakaf pada Bank Wakaf Tani digunakan untuk membiayai seluruh kegiatan pertanian. Bagi petani yang tidak memiliki lahan, maka dana wakaf dari Bank Wakaf Tani dapat digunakan untuk menyewa lahan dan pengerjaan kegiatan pengolahan pertanian yang lain. Sedangkan bagi petani yang mempunyai lahan pertanian namun kekurangan modal, maka dana wakaf dari Bank Wakaf Tani dapat digunakan untuk kegiatan pembelian benih pertanian, pembelian pupuk, pengairan dan lain sebagainnya.

Pemberdayaan dana wakaf melalui Bank Wakaf Tani dapat diakses oleh petani individu maupun oleh kelompok tani dalam sekala besar. Konsep Bank Wakaf Tani ini juga disertai dengan kegiatan pendampingan mental spiritual dan kewirausahaan kepada petani dengan harapan para petani mendapatkan semangat baru dalam mencari rezeki secara halal serta mampu menumbuhkan giat berwakaf dari petani (Rozalinda, 2015: 264). Satu hal penting bahwa dana yang pada pada Bank Wakaf Tani tidak seluruhnya disalurkan untuk pembiayaan melainkan sebagian diletakkan untuk deposito pada bank umum syariah. Hal ini untuk menjaga kelestarian dan ketetapan asset wakaf yang menjadi salah satu inti dari diperbolehkannya wakaf. Saidi berpendapat bahwa asset wakaf haruslah asset yang berputar serta mempunyai fungsi produktif, sehingga menghasilkan surplus dan dari surplus tersebut terdapat ast yang dapat terus dialirkan, tanpa mengurangi modalnya sama sekali. Sehingga pada saat barang modal itu aus, using, atau bahkan habis dipakai, maka asset wakaf dapat diperbaharui kembali dari hasil surplus tersebut (Saidi, 2012: 86). Persoalan pengembangan asset wakaf memang masih menjadi perdebatan yang tak berujung di kalangan ulama Islam. Bagi sebagian ulama yang secara konservatif berpegang teguh pada mazhab Imam Syafi'i, asset wakaf tidak boleh dirubah ataupun ditukar dengan apapun. Dalam menyikapi hal ini, penulis berpegang pada teori al-maslahah almursalah Imam Malik. Pemberdayaan wakaf tunai yang optimal dapat memberikan dampak kemaslahatan sosial yang luar biasa.

Bank Wakaf Tani berbasis mudharabah adalah salah satu instrumen yang layak untuk pemberdayaan wakaf tunai di bidang pertanian. Konsep Bank Wakaf Tani merupakan salah satu bentuk kepatuhan terhadap syariah karena didasarkan pada kontrak mudharabah. 
Penguatan Sektor Pertanian Melalui Bank Wakaf Tani Berbasis Mudharabah

2. Skema Bank Wakaf Tani (BWT) berbasis Muzara'ah.

Konsep Bank Wakaf Tani (BWT) merupakan bentuk keterlibatan pemerintah yang dalam hal ini Kementerian Pertanian secara langsung dalam rangka mendorong serta menumbuhkan giat berwakaf di kalangan masyarakat. Konsep Bank Wakaf Tani juga dihadirkan sebagai salah satu instrument pemberdayaan asset wakaf tunai untuk menguatkan sektor pertanian. Secara sederhana, Bank Wakaf Tani merupakan lembaga keuangan khusus di bidang wakaf yang diperuntukkan secara khusus juga untuk memberdayakan para petani yang kekurangan modal. Adapun pendanaan BWT ini berasala dari asset wakaf tunai yang digelontorkan oleh Kementerian Pertanian.

Kontrak mudharabah adalah salah satu kontrak yang telah sesuai dengan kepatuhan syariah. Kontrak mudharabah telah dibenarkan baik oleh Al-Quran, Sunnah, ijma ulama maupun 'urf. Kontrak mudharabah memiliki sifat keadilan, hal ini dikarenakan dalam kontrak mudharabah terdapat porsi yang sama keterlibatan kedua belah pihak. Disamping itu, pembagian bagi hasil dalam kontrak mudharabah juga diserahkan sepenuhnya kepada kedua belah pihak yang berkontrak. Bahkan lebih lanjut kontrak mudharabah dikembangkan dalam system pembiayaan modern baik di perbankan maupun lembaga keuangan lain. Mudharabah memiliki fleksibilitas yang tinggi dan potensi yang besar untuk pemberdayaan wakaf tunai. Meskipun konsep Bank Wakaf Tani hadir untuk memberdayakan sektor pertanian, dibandingkan dengan akad kerjasama di bidang pertanian seperti muzara'ah dan mukhabarah, akad mudharabah lebih potensial untuk digunakan. Pemberdayaan sektor pertanian melalui pengembangan asset dana wakaf lebih memungkinkan diterapkan dengan menggunakan kontrak mudharabah. Kontrak mudharabah, dalam penerapannya tidak bergantung pada kepemilikan lahan maupun benih, sehingga kontrak ini lebih leluasa untuk diterapkan.

Bank Wakaf Tani terbentuk dari dana wakaf tunai yang berasal dari Kementerian Pertanian. Kementerian Pertanian menggelontorkan dana wakaf tunai kepada kelompok tani. Dengan bimbingan dan pendampingan, kelompok tani ini kemudian mendirikan Bank Wakaf Tani. Setelah Bank Wakaf Tani terbentuk, petani yang kekurangan modal mengajukan pembiayaan untuk dapat mengakses dana wakaf tunai. Secara lebih rinci, penulis menjelaskan skema Bank Wakaf Tani pada bagan berikut:

1. Kementerian Pertanian memberikan pendampingan kepada Kelomok Tani terkait dengan pendirian Bank Wakaf Tani. Dalam melakukan pendampingan terhadap kelompok tani, Kementerian Pertanian harus melibatkan pihak yang ahli dalam pendirian 
Lembaga Keuangan dan pihak yang layak dijadikan sebagai Nazhir Wakaf.

2. Kementerian Pertanian menggelontorkan dana wakaf tunai kepada Bank Wakaf Tani yang dikelola oleh kelompok tani, tenaga professional pendirian Bank Wakaf Tani, serta Nazhir Wakaf. Untuk selanjutnya kesemua pengelola Bank Wakaf Tani ini disebut sebagai nazhir wakaf.

3. Petani yang kurang mampu mengajukan pembiayaan mudharabah untuk mengelola pertanian dengan system bagi hasil yang prosentasenya lebih berpihak kepada petani.

4. Petani mengembalikan dana pembiayaan beserta dengan hasil keuntungan kepada Bank Wakaf Tani.

Pendampingan yang diberikan Kementerian Pertanian terhadap Kelompok Tani adalah pendampingan persiapan pendirian Bank Wakaf Tani. Oleh karena itu, dalam proses pendampingan, kementerian Pertanian harus melibatkan pihak yang professional terhadap perihal kelembagaan. Selain itu, Kementerian Pertanian juga harus menggandeng nadzir, hal ini diperlukan, mengingat kedudukan Bank Wakaf Tani adalah sekaligus sebagai nazhir wakaf.

Dalam memberikan pembiayaan kepada petani, Bank Wakaf Tani diharuskan menerapkan prinsip kehati-hatian sebagaimana diterapkan oleh lembaga keuangan lain. Hal ini mengingat sumber dana pembiayaan adalah harta wakaf yang wajib dijaga kelestariannya, sehingga sebisa mungkin hal-hal yang menyebabkan berkurangnya harta wakaf tunai dihindari.

Prosentase bagi hasil juga harus memiliki tingkat keeberpihakan yang kuat kepada petani. Hal ini mengingat Bank Wakaf Tani bukanlah lembaga keuangan yang menekankan pada keuntungan. Bank Wakaf Tani menitikberatkan pada social oriented. Keuntungan yang diperoleh Bank Wakf Tani hanya sebatas pada untuk membayar jasa (ujrah) bagi pengelola Bank Wakaf Tani.

Model pengembangan wakaf melalui lembaga keuangan yang dikelola secara professional bukanlah hal yang baru di Indonesia. Tabung Wakaf Indonesia (TWI), Baitul Maal Muamalat (BMM), Yayasan Wakaf Bangun Nurani Bangsa, Rumah Wakaf Indonesia (RWI), Global Wakaf Act adalah beberapa lembaga wakaf yang telah ada dan berbadan hukum resmi (Deks Bank Indonesia, 2016: 70-87). Namun, kesemua lembaga wakaf tersebut pendanaannya berasal dari masyarakat umum. Sehingga diperlukan strategi yang unggul untuk memobilisasi dana. Berbeda dengan konsep Bank Wakaf Tani. Bank Wakaf Tani hadir untuk melengkapi sekaligus memberikan warna baru lembaga pengelolaan wakaf. 
Penguatan Sektor Pertanian Melalui Bank Wakaf Tani Berbasis Mudharabah

\section{KESIMPULAN}

Wakaf tunai memberikan potensi yang sangat besar bagi pemberdayaan ekonomi suatu negara. Pemberdayaan wakaf tunai di Indonesia masih belum optimal. Dalam hal pemberdayaan wakaf, Indonesia masih tertinggal oleh negara-negara lain seperti Bangladesh, Singapura, maupun Saudi Arabia. Optimalisasi pemberdayaan wakaf tidak cukup dilakukan dengan sosialisasi maupun edukasi terhadap masyarakat. Masyarakat perlu keteladanan yang riil dari pemerintah. Konsep Bank Wakaf Tani merupakan konsep keteladanan Kementerian Pertanian dalam berwakaf yang diperuntukkan khusus untuk penguatan sektor pertanian di Indonesia. Penciptaan Bank Wakaf Tani yang memenuhi kepatuhan syariah dengan akad mudharobah sebagai pelaksanya dapat dijadikan basis untuk meningkatkan kemitraan bersama petani.

Pendanaan Bank Wakaf Tani sepenuhnya berasal dari asset wakaf yang dikeluarkan oleh Kementerian Pertanian. Dengan memberikan pendampingan secara masif kepada Kelompok Tani, Kementerian Pertanian bersama dengan Kelompok Tani mendirikan Bank Wakaf Tani. Sasaran dari Bank Wakaf Tani ini adalah para petani yang kurang mampu. Untuk mengakses dana dari Bank Wakaf Tani petani dapat mengajukan pembiayaan mudharabah dengan skema bagi hasil yang disepakati. 


\section{DAFTAR PUSTAKA}

Atabik, Ahmad, 2014. Manajemen Pengelolaan Wakaf Tunai di Indonesia. Jurnal ZISWAF(1), 82-107)

Bank Indonesia, Wakaf: Pengaturan dan Tata Kelola Yang Efektif, Departemen Ekonomi dan Keuangan Syariah-Bank Indonesia, 2016.

Direktorat Pemberdayaan Wakaf, Pedoman Pengelolaan Wakaf Tunai, Kemenag RI, 2007.

Karim, Shamsiah Abdul, Pengurusan dan Pembangunan Wakaf di Singapura, (Kertas Kerja Konvensyen Wakaf 2006 di Hotel Legend, Kuala Lumpur, 12-14 September), 2006.

Lubis, Suhrawardi K. dkk., Wakaf dan Pemberdayaan Umat, Jakarta: Sinar Grafika dan UMSU Publisher, 2010.

Nasution, Mustafa E. dan Uswatun Hasanah, ed. Wakaf Tunai Inovasi Finansial Islam . Jakarta: PSTTI-UI, 2006.

Rozalinda, Manajemen Wakaf Produktif, Jakarta: Raja Grafindo Persada, 2015

Saidi, Zaim, Stop Wakaf dengan Cara Kapitalis: Begini Cara Berwakaf dan Berzakat yang Tepat, Yogyakarta: Delokomotif, 2012.

Wadjdy, Farid dan Mursyid, Wakaf dan Kesejahteraaan Umat: Filantrofi Islam yang Hampir Terlupakan, Yogyakarta: Pustaka Pelajar, 2007.

Zuhaily, Wahbah, al-Figh al-Islamy wa Adillatuhu, Vol. v , Dar al Fikr, Damaskus, 2008 